\title{
The normative demands of wine governance
}

Citation for published version (APA):

Eliantonio, M. (2019). The normative demands of wine governance. Maastricht University. https://doi.org/10.26481/spe.20190503me

Document status and date:

Published: 03/05/2019

DOI:

10.26481/spe.20190503me

Document Version:

Publisher's PDF, also known as Version of record

\section{Please check the document version of this publication:}

- A submitted manuscript is the version of the article upon submission and before peer-review. There can be important differences between the submitted version and the official published version of record.

People interested in the research are advised to contact the author for the final version of the publication, or visit the DOI to the publisher's website.

- The final author version and the galley proof are versions of the publication after peer review.

- The final published version features the final layout of the paper including the volume, issue and page numbers.

Link to publication

\footnotetext{
General rights rights.

- You may freely distribute the URL identifying the publication in the public portal. please follow below link for the End User Agreement:

www.umlib.nl/taverne-license

Take down policy

If you believe that this document breaches copyright please contact us at:

repository@maastrichtuniversity.nl

providing details and we will investigate your claim.
}

Copyright and moral rights for the publications made accessible in the public portal are retained by the authors and/or other copyright owners and it is a condition of accessing publications that users recognise and abide by the legal requirements associated with these

- Users may download and print one copy of any publication from the public portal for the purpose of private study or research.

- You may not further distribute the material or use it for any profit-making activity or commercial gain

If the publication is distributed under the terms of Article $25 \mathrm{fa}$ of the Dutch Copyright Act, indicated by the "Taverne" license above, 


\section{The Normative Demands of Wine Governance}

Inaugural Lecture delivered on Friday 3 May 2019, by Mariolina Eliantonio, appointed as professor of 'European and Comparative Administrative Law and Procedure' at the Faculty of Law of Maastricht University 
Prof. Dr. Mariolina Eliantonio Faculty of Law

The Normative Demands of Wine Governance 
Dear Madam Rector, dear Mr Dean, dear colleagues, dear friends, dear Paul, cara mamma,

\section{Introduction}

In December 2008, a bit more than 10 years ago, I stood in this very same spot to defend my $\mathrm{PhD}$ thesis entitled "Europeanisation of Administrative Justice? The Influence of the European Court of Justice's case law in Italy, Germany and England". 1 On that day, as all PhD candidates at this University, I was allowed to start the defense of my PhD thesis with a 15-minute presentation on my research project and its main results. Back then, I stood here and opened my speech with this slide, and told the story of an Italian applicant, Mariolina, who, in case her academic career would fail, was planning on opening an Italian restaurant in Maastricht, serving the gastronomical and enological specialties from her Region, Abruzzo. I suppose being here today shows that, somehow, my academic career did not fail, and I did not need to resort to my plan B. However, while standing here today, delivering my inaugural lecture as Professor of European and Comparative Administrative Law and Procedure, I am again talking about wine. I suppose you can say that what the EU defines as "the product obtained exclusively from the total or partial alcoholic fermentation of fresh grapes, whether or not crushed, or of grape must" ${ }^{2}$ might well be considered the leitmotiv or red line of my academic career.

On the day in which I defended my PhD thesis, I took the denial of the Dutch authorities to grant me an authorization to offer delicious wines from Abruzzo as an example of a possible situation in which an individual would need to resort to national courts to seek judicial protection against the allegedly unlawful behavior of national authorities. In that story, I had been discriminated on grounds of nationality because the Dutch authorities had decided not to grant me an authorization on the ground that, according to Dutch law, only Dutch nationals could open bars and restaurants in the Netherlands: in such situations, individuals can only seek judicial protection from national courts, which are the main enforcers and protectors of the rights which we derive from European law.

Neither my interest for wine nor that for courts has diminished with time. And so here I stand today to talk again about wine and courts. In fact, you could say that my interest for both has only grown. I suppose that, as far as wine is concerned, having met Paul, my French better half, contributed to me becoming more open-minded (or perhaps less intolerant?) towards French wine. As far as my interest for courts is concerned, I have continued, and I intend to continue as part of the research carried out through my chair, to explore the role of courts in the process of European integration. And again, courts - and the legal phenomena that I study - and wine are very much intertwined.

\footnotetext{
${ }^{1}$ M. Eliantonio, Europeanisation of Administrative Justice? The Influence of the ECJ's Case Law in Italy, Germany and England (Europa Law Publishing, 2008).

2 This is the definition contained in Part II of Annex VII to Regulation (EU) No 1308/2013 of the European Parliament and of the Council of 17 December 2013 establishing a common organisation of the markets in agricultural products [2013] OJ L 347, p. 671-854.
} 
In the rest of this lecture, I will present to you three instruments of governance which are all linked with wine, namely shared and transnational administration, soft law, and standardization, and I will show how these instruments challenge the traditional role of courts and, thereby, possibly endanger the judicial protection of individuals against the actions of public authorities. What are then the "normative demands" of wine governance?

\section{Shared and transnational administration}

The first instrument of wine governance which I would like to present you today is the system of Protected Designation of Origin. The wonderful Cerasuolo d'Abruzzo wine, a cherry-red, intense rosé, is such an example. ${ }^{3}$

The Protected Designation of Origin is a label which refers to an area, a specific place or, in exceptional cases, the name of a country, and which is used for agricultural products or foodstuffs. To receive this label, the entire product must be traditionally and entirely manufactured within the specific region and thus acquire unique properties.

To register the name of a product, producers need to lay down the product's specifications and link to the geographical area. The application is sent to national authorities for scrutiny and then, on the basis of the assessment made by the national authorities, it is forwarded to the European Commission, who will examine the request. The European Commission will then decide if the product will be protected under the quality scheme requested. ${ }^{4}$

This is a typical example of a system called "shared administration", that is a system in which national authorities and EU authorities collaborate, at different moments, with various intensities and with various types of activities, to the implementation of EU law. ${ }^{5}$ I just gave you the example of wine, but this system of collaboration, between national and European authorities and between national authorities themselves, exists in virtually all fields of EU law, ranging from competition, to fisheries, to the marketing authorization of medicines, the supervision of financial institutions or the regulation of asylum protection.

\footnotetext{
${ }^{3}$ Registration under "PDO-IT-A0743" available at https://ec.europa.eu/agriculture/sites/agriculture/files/wine/e-bacchus/updates en.pdf ${ }^{4}$ Commission Delegated Regulation (EU) 2019/33 of 17 October 2018 supplementing Regulation (EU) No 1308/2013 of the European Parliament and of the Council as regards applications for protection of designations of origin, geographical indications and traditional terms in the wine sector, the objection procedure, restrictions of use, amendments to product specifications, cancellation of protection, and labelling and presentation [2019] OJ L 9, p. 2-45.

5 See further M Eliantonio, 'Judicial review in an integrated administration: the case of "composite procedures"' (2014) 7 Review of European Administrative Law 65; H C H Hofmann, G C Rowe, A. H. Türk, Administrative Law and Policy of the European Union (OUP 2011).
} 
This system exists, in fact, since the creation of the project of European integration, but it has recently increased in importance, and has seen the growing involvement of new institutional actors, such as the European agencies or the European Central Bank.

Intertwined with this phenomenon, there is another one, which is generally referred to as "transnational administrative law". What does this mean? It refers to situations in which an act taken by the competent authorities has effects outside the territory of the Member State to which the authority belongs. ${ }^{6}$ Said like that, this sounds very exotic, but in fact many sitting in this room today hold a transnational administrative law in their pockets or in their bags: their driving licence, issued by one national authority, but enabling the holder to drive in the whole European Union. Also the system of transnational administrative law exists since many years, but it has increased in importance in the last decade. We can see examples of transnational administrative acts in fields as diverse as those concerning the marketing of mineral water, diploma recognition, the shipment of waste or the Schengen area.

What is then the problem with all of this?

That while the system of decision-making has become more and more shared, and transnational, the system of judicial protection is, in principle, still anchored to a strict separation of jurisdiction. Every national judge, in other words, is in principle competent only for the acts issued by the authorities which operate in the national territory, even if they were only parts of a bigger - horizontal or vertical - decision-making process. So a German judge is authorized to review the lawfulness of German administrative measure, but if this German measure is the product of a bigger decision-making process which originated, for example, in France or at the EU level, the German judge is in principle not competent to look at the French or EU parts of the decision-making process, for which the French and EU judges respectively remain competent.

And what is the problem with this, you may be asking. That, because of this strict separation of jurisdiction, some acts may fall "in the cracks of the system" and not be able to be judicially reviewed. ${ }^{7}$ Concretely this means means that it might very difficult or even impossible for citizens, companies or other actors to challenge the actions of the EU or national authorities, like the registration or denial of registration of a product with a protected designation of origin. This denial of justice would be problematic from the perspective of compliance with the rule of law, ${ }^{8}$ and with the principle of effective

\footnotetext{
${ }^{6}$ See further M. Ruffert, 'The transnational Administrative Act', in O.J. Jansen, B. Schöndorf-Haubold (Eds) The European Composite Administration (Intersentia, 2011), 277 ff; M. Gautier, 'Acte administratif transnational et droit communautaire', in J.-B.Auby, J. Dutheil de la Rochère (Eds) Droit Administratif Européen (Bruylant, 2014) 1303 ff; J.J. Pernas García, 'The EU's Role in the Progress Towards the Recognition and Execution of Foreign Administrative Acts: The Principle of Mutual Recognition and the Transnational Nature of Certain Administrative Acts', in J. Rodrigo-Arana Muñoz (Ed) Recognition of Foreign Administrative Acts (Springer, 2016), 15-31; L. De Lucia, Amministrazione transnazionale e ordinamento europeo (Giappichelli, 2009).

${ }^{7}$ See the Introduction to the ReNEUAL Model Rules; Book I - General Provisions; para. 27, where the phrase "black hole" is used.

${ }^{8}$ See Case 294/83, Parti écologiste "Les Verts" v European Parliament, ECLI:EU:C:1986:166, para 23, where the Court of Justice spoke of a "Community based on the rule of law".
} 
judicial protection enshrined in the Charter of Fundamental Rights of the European Union. ${ }^{9}$

In a number of cases,$^{10}$ the Court of Justice has held that, if a national preparatory measure, such as the opinion of a national competent authority, is decisive for the outcome of a decision-making process which is concluded at EU level, national courts should be able to review these acts of the national authorities which are only intermediate or preparatory in the decision-making process, notwithstanding what national procedural rules would require. A more recent case, one of the many, I am afraid, which has involved the former Italian Prime Minister, Mr Berlusconi, added to the earlier case law that, when instead the final EU measure is not pre-determined by the national preparatory measure, the Court of Justice is competent to review the entirety of the decision-making process, including its national part. ${ }^{11}$

The first question, and one which has not yet been explored, is whether national courts have indeed followed the approach of the Court of Justice. While a number of authors have explored the question of the division of competences between national and European courts in the case of shared administration, ${ }^{12}$ more comparative research should be carried out as to how national courts have considered the issue of reviewability of intermediate and preparatory measures in the system of shared administration.

Secondly, what these cases tackle is the question of division of jurisdiction between national courts and European courts. But can we apply these conclusions to the horizontal delimitation of jurisdiction between national courts? Here the issue of shared administration is intertwined with that of transnational administrative law and the growing situations of horizontal sharing of information between Member States authorities. Take an alert issued in the context of the Schengen Information System. ${ }^{13}$ In this case, one national authority enters a piece of information concerning an individual in a database and another authority of another Member State can take a decision concerning that individual (for example a decision of expulsion from the national territory), on the basis of that piece of information.

In a series of cases, the French Conseil d'État has reviewed the lawfulness of a German Schengen alert taken on the basis of the applicable EU legislation. ${ }^{14}$

\footnotetext{
${ }^{9}$ Article 47.

10 Most notably in Case C-97/91, Oleificio Borelli v Commission EU:C:1992:491.

11 Case C-219/17 Silvio Berlusconi and Fininvest $v$ Banca d'Italia and IVASS [2018] ECLI:EU:C:2018:1023.

${ }^{12}$ Eg F. Brito Bastos, 'The Borelli Doctrine Revisited: Three Issues of Coherence in a Landmark Ruling for EU Administrative Justice' (2015) 8 Review of European Administrative Law 269; F. Brito Bastos, 'Derivative Illegality in European Composite Administrative Procedures' (2018) 55 Common Market Law Review 101; S. Alonso de León, Composite Administrative Procedures in the European Union (lustel/UCLM 2017) 251-318; J. Fernández Gaztea, 'A Jurisdiction of Jurisdictions' (2019) 12 Review of European Administrative Law 9.

${ }^{13}$ Regulation (EC) No 1987/2006 of the European Parliament and of the Council of 20 December 2006 on the establishment, operation and use of the second generation Schengen Information System (SIS II) [2006] OJ L 381, p. 4-23.

${ }^{14}$ Conseil d'Etat, Forabosco, Judgment of 9 June 1999, No. 190384.
} 
However, no comparative and coherent research has been carried out on the attitudes of national courts on the review of foreign national administrative measures. ${ }^{15}$

Furthermore, the horizontal system of information sharing, and in general, the question of transnational administrative acts raise a number of additional questions: what are the consequences of a national courts ruling on the unlawfulness of a foreign administrative act? To which extent should the principle of res judicata apply in such situations? How to avoid the duplication of procedures leading to possibly contradictory judgments in several Member States? These are all relevant and unexplored questions which I hope to research with, amongst others, the colleagues which are part of the "Transnational Administrative Law Network".

What are then the "normative demands" of shared and transnational administration? That no action falls in "the cracks of the system", and, thereby, both at national and European level, that "effective judicial protection" is ensured, as required by the Charter of Fundamental Rights. How and to what extent this is currently ensured is certainly a matter for further investigation.

\section{Soft law}

The second instrument of wine governance which I would like to present to you today is the European Food Safety Authority Guidance on the establishment of the residue definition for dietary risk assessment. This document guides the complex process of identifying the residue components that should be considered for dietary risk assessments of chemical active substances in, amongst others, wine - of course. ${ }^{16}$

This document is an example of what is usually referred to as "soft law", namely measures which come in various shapes and forms - they may be called recommendation, guidance document, working document, guideline or something else - but they have all in common the feature that they are not legally binding. The use of soft law in European law dates back to 1962, when the European Commission issued the "Christmas notices", ${ }^{17}$ pieces of soft law in the field of competition law, and today is present in virtually all policy fields, ranging from citizenship, to energy, food safety, the protection of endangered species, the supervision of credit institutions and the fight against social exclusion. Soft law is also more and more often inextricably linked to hard law. It serves to set the course of action of EU and national institutions alike, thereby avoiding arbitrary behavior, and to interpret hard law provisions in a legislative context of interestingly technical and technological nature.

\footnotetext{
${ }^{15}$ See only for a general perspective J. Rodrigo-Arana Muñoz (Ed) Recognition of Foreign Administrative Acts, (Springer, 2016).

${ }^{16}$ https://efsa.onlinelibrary.wiley.com/doi/full/10.2903/j.efsa.2016.4549

17 Commission, Notice on exclusive dealing contracts with commercial agents [1962] OJ 139/2921; Commission, Notice on patent licensing agreements [1962] OJ 139/2922.
} 
In the words of Advocate General Bobek, soft law measures contain "a type of imperfect norm: on the one hand, they clearly have the normative ambition of inducing compliance on the part of their addressees. On the other hand, no instruments of direct coercion are attached to them". ${ }^{18}$ What should we understand with the phrase "normative ambition of inducing compliance"?

As held by Professor Linda Senden, and repeated in countless studies after her, soft law "may have certain (indirect) legal effects" and "may produce practical effects". ${ }^{19}$ The word "may" with references to the possible legal and practical effects of soft law, and its uncertain connotation, is key to the discussion concerning soft law. Even the Court of Justice displays a rather unclear view of the "bindingness" of soft law in its preliminary references, by imposing duties on national courts to take EU soft law into consideration, ${ }^{20}$ while noting at the same time that such instruments cannot be binding at the national level. ${ }^{21}$

Do national authorities and courts apply soft law? What effects do they give to it? Do national courts accept to judicially review soft law despite the fact that it is formally not binding? The Soft Law Research Network, ${ }^{22}$ and the many great colleagues who are part of it, have started to research this topic, and have discovered that the attitudes of national courts and authorities towards soft law varies greatly. These differences might be due to different institutional cultures, different relationships with national soft law, but also more dogmatically to the very idea of what "law" is and what the hierarchy of sources in a legal system is or ought to be. However, research on this topic is lacking, and the Soft Law Research Network is one of the first types of endeavors of this kind. ${ }^{23}$ Much more research is needed to understand how national courts apply EU law and soft law in particular. The application of EU law on the ground is, indeed, an unchartered territory for many perspectives.

The beauty and at the same time the challenge of these kinds of research projects is well known to all those who embark upon comparative law research. Language barriers, understanding the differences in national systems but also national legal cultures, the availability of primary sources are all difficulties which many of the colleagues in this room have grappled with at one point or the other in their career. This kind of research needs to be, in my view, networked-research with like-minded colleagues. The Soft Law Research Network has laid the foundations for further -

\footnotetext{
${ }^{18}$ C-16/16 P, Opinion of Advocate General Bobek delivered on 12 December 2017, Kingdom of Belgium v European Commission ECLI:EU:C:2017:959, para. 86.

${ }^{19} \mathrm{~L}$. Senden, Soft Law in European Community Law (Hart Publishing 2004).

${ }^{20}$ Case 322/88, Grimaldi v Fonds des maladies professionnelles, ECLI:EU:C:1989:646, para 18.

${ }^{21}$ Case C-526/14, Kotnik and Others, ECLI:EU:C:2016:570, para 45.

22 https://www.solar-network.eu/home/

${ }^{23}$ The few exceptions are e.g Z. Georgieva, 'The judicial reception of competition soft law in the Netherlands and the UK' (2016) 12 European Competition Journal, 54; Z. Georgieva, 'Competition soft law in French and German courts: A challenge for online sales bans only?' (2017) 24 Maastricht Journal of European and Comparative Law, 175; T. Devine and M. Eliantonio, 'EU soft law in the hands of national authorities: The case study of the UK Competition and Markets Authority' (2018) 11 Review of European Administrative Law, 49.
} 
much needed - comparative research on how national courts and authorities apply EU soft law.

This research should reveal whether the potential benefits of soft law to induce harmonization, to reduce the need for infringement proceedings, to aid national courts and authorities in implementing EU law do materialize in practice.

Soft law is praised for many reasons, but it is also criticized heavily for its extreme lack of transparency ${ }^{24}$ in the adoption procedures, which is claimed to enhance the discretion of the EU institutions to the detriment of Member State competences, ${ }^{25}$ and to reduce the role of the European Parliament in EU decision-making ${ }^{26}$ Soft law is also criticized because it is an instrument which does not seem to ensure proper consultation with the stakeholders. ${ }^{27}$

And what is the problem with that?

That if soft law is indeed producing some legal effects, if it is being used and applied by its end-users, if it is, in other words, almost perceived as "law" by them, at the same time soft law did not pass through the approval of a legislator, and might therefore be considered as by-passing the democratic forms of control. The Guidance Document of the European Food Safety Authority which I showed you before, for example, was adopted by a European agency without any form of parliamentary control. However, what kind of consultation and participation requirements apply to EU soft law, and which mechanisms of consultation and participation have been put to practice until now has not been coherently studied and should be the object of further investigation.

What are then the "normative demands" of soft law? That national and European courts engage with soft law. As held in earlier studies, law should be seen as a continuum, varying from non-law through soft law to hard law forms, ${ }^{28}$ and regulation is increasingly hybrid, including both soft and hard law features. ${ }^{29}$ In these circumstances, it is no longer viable to strictly separate hard law from soft law, as if they were two ontologically distinct entities and, as a consequence, it is no longer sustainable for courts to refuse to engage with soft law on the grounds that such

\footnotetext{
${ }^{24}$ L. Senden, 'Soft Post-Legislative Rulemaking: A Time for More Stringent Control', (2012) 19 European Law Journal, 65.

${ }^{25}$ F. Snyder, 'Soft Law and Institutional Practice in the European Community', in S. Martin (Ed.), The Construction of Europe (Springer, 1994), 201-203.

${ }^{26}$ Résolution du Parlement européen du 8 mai 1969, sur les actes de la collectivité des États membres de la Communauté ainsi que les actes du Conseil non prévus par les traités adoptés à la suite du rapport fait au nom de la Commission juridique par M. Burger [1969] OJ C63/18.

${ }^{27}$ R. Baldwin, Rules and Government (Oxford University Press, 1997), 284; J. Scott 'In Legal Limbo: PostLegislative Guidance as a Challenge for European Administrative Law', (2011) Common Market Law Review 48(2), 329-355.

${ }^{28}$ K.W. Abbott and D. Sindal, 'Hard and Soft Law in International Governance', (2000) 54 International Organization, 421; F. Terpan, 'Soft Law in the European Union - The Changing Nature of EU Law', (2015) 21 European Law Journal, 68.

${ }^{29}$ G. De Búrca and J. Scott, 'Introduction: New Governance, Law and Constitutionalism', in G. De Búrca and J. Scott (Eds.), Law and New Governance in the EU and the US (Hart Publishing, 2006); D.M. Trubek and L.G. Trubek, 'New Governance and Legal Regulation: Complementarity, Rivalry and Transformation', (2007) 13 Columbia Journal of European Law, 539.
} 
measures do not produce legally binding effects. While European and national courts ought, therefore, to embrace hybridity, this ought not to mean a new chance for EU institutions to by-pass the basic tenets of the rule of law, including transparency, reasons giving and accountability, but acknowledging that soft law is here to stay and needs to be both used and controlled by the European and national courts. This requires a more streamlined approach to procedural requirements concerning the adoption of soft law instruments, which in turn might be of use for the courts when engaging with soft law. Discussions on EU soft law have certainly not come to an end.

\section{Standardisation}

The third and final instrument of wine governance which I would like to present to you today is an oenological practice concerning a very special type of wine, dear to many sitting in this room today, namely sparkling wine. ${ }^{30}$ This practice belongs to the International Code of Oenological Practices which is issued by the International Wine and Vine Organisation, ${ }^{31}$ an organization whose principal function is the creation of internationally harmonised and accepted standards for the production of vitivinicultural products.

This is only one example of how standards are relevant for us. Standards are really everywhere, from the toys our children play with, to the way in which companies should prepare their accounting books, or test the safety of a medicine, or the safety of the lifts in this building, nearly everything is regulated by standards, made by various public, private, or hybrid organisations. The employment of standards for regulatory purposes is today a key factor in EU policy-making, since it contributes, amongst others, to the removal of the technical barriers to trade, and is said to support innovation by stimulating dissemination of new technologies. If we consider specifically product standards (such as those for toys or for lifts), it could also be added that the technical requirements set via these standards aim to deliver safe products on the market and, by doing so, to protect health and the environment. ${ }^{32}$

These standards are developed within organizations of various nature and status, outside the legal system of the EU, and often by bodies to which some, but not all, Member States may be party. What is striking is that they enter the EU legal system and become "EU law" to different extents.

In the case of the wine standards, they are made by an organization to which some but not all EU Member States, are party, and, because EU law makes reference to

\footnotetext{
30 http://www.oiv.org/en/technical-standards-and-documents/oenological-practices/oenologicalpractices-sparkling-wines

31 http://www.oiv.org/en/

32 See further Jacques Pelkmans, 'The New Approach to Technical Harmonisation and Standardisation', (1987) 25 Journal of Common Market Studies, 249; Michelle Egan, 'Regulatory Strategies, delegation and European market integration', (1998) 5 Journal of European Public Policy, 485; Harm Schepel, The Constitution of Private Governance - Product Standards in the Regulation of Integrating Markets (Hart, 2005).
} 
them, ${ }^{33}$ they become binding EU law. Other standards may become EU soft law, as is the case with standards which are created to ensure that certain medicines are safe. Other standards, such as those concerning toys and lifts, to come back to the example I gave above, are instead in principle not binding, but not using these standards entails a lengthy and costly process which most producers do not want to engage with. For this reason, one can say that these standards are de facto binding. ${ }^{34}$

What is the problem with that?

That standards often become binding EU law, or de facto binding for market operators, but they have been created by bodies which are outside the EU legal system and do not pass function according to the normal forms of parliamentary democratic control. Furthermore, because these standards are created by these private or hybrid bodies, it is questionable whether the usual public law guarantees apply to them.

Take for example the question of accessibility. Recently, with regards to certain standards which are relevant in the EU legal system, the Court of Justice has held that they "form part of EU law". ${ }^{35}$ Yet, these standards are not freely accessible and the standardization bodies who are the authors of these standards hold the copyright on them and make them available only against payment. How can we reconcile the idea of something being part of EU law and at the same time the fact that they are only available against payment? Furthermore, while the EU is committed to openness and public participation, ${ }^{36}$ it is questionable to which extent one can speak of an effective stakeholder participation in the standard-making process in light of the economic, informational and expertise asymmetries of societal stakeholders (such as those representing consumers or environmental concerns) vis-à-vis the industry. More empirical research would be necessary to really understand the participatory reality of the various standard-making processes at European and global level. Again here I plead for a "networked-research" with the many colleagues who, around the globe, try understand the operation of standardization processes in various fields, in order to unveil the common shortcomings and challenges.

One could say that the dubious legal status of the standard-setting bodies, and the even more dubious applicability of public law principles to their activities, makes the role of courts all the more important. Recently, at least for certain standards, we can observe a growing engagement of European courts, but we still know very little about

\footnotetext{
${ }^{33}$ Article 80(3)(a) of Regulation (EU) No 1308/2013 of the European Parliament and of the Council of 17 December 2013 establishing a common organisation of the markets in agricultural products [2013] OJ L 347, p. 671-854

34 This is the case for the so-called New Approach, on which see further Harm Schepel, The Constitution of Private Governance. Product Standards in the Regulation of Integrating Markets (Hart Publishing 2005); J. Falke, 'Achievements and Unresolved Problems of European Standardization: The Ingenuity of Practice and the Queries of Lawyers', in C. Joerges, K.-H. Ladeur and E. Vos (eds.), Integrating Scientific Expertise into Regulatory Decisionmaking- National Traditions and European Innovations (Nomos, 1997),187; Harm Schepel, 'The New Approach to the New Approach: The Juridification of Harmonized Standards in EU Law', (2013) 12 Maastricht Journal of European and Comparative Law, 523.

${ }^{35}$ Case C-613/14, James Elliott Construction Limited v Irish Asphalt Limited EU:C:2016:821.

${ }^{36}$ Article $1(2)$ and 10(3) TEU.
} 
what is happening at national level. Much more comparative research would be needed to see whether and how national courts engage with the various standards which are relevant in the EU legal system.

What are then the "normative demands" of standardization?

In all truth, ladies and gentlemen, I am not sure. I am still thinking about this and, if you do not mind, I will raise more questions than I will give answers. Because indeed, while I pleaded one moment ago for the need for a greater involvement of courts to control European and global standards, a very much open question is: against which legislative framework should these standards be judged? Should European, or perhaps global, principles of administrative law be regarded as the reference?

And to make matters more complicated, would a greater engagement of courts not jeopardise the effectiveness of the system, which is based on the active role of those being regulated in the creation of the norms which will regulate them? Would a growing judicialisation of standardization not threaten the very raison d'être of this form of regulation?

And finally, and this is a question which goes well beyond standards and is very much at the core of modern regulation, are courts the correct forum to control highly technical and complex choices made by experts in the field? While the topic is not new as such, and has gained new momentum in European scholarship, ${ }^{37}$ I think that much more also comparative - research is needed to study the similarities and differences in approach of national and European courts towards the review of complex technical and scientific decisions to establish possible common trends in the scope and intensity of judicial review and whether the requirement of effective judicial protection I mentioned before, or the uniform application of EU law, are currently endangered.

\section{Conclusions and thanks}

Dear ladies and gentlemen, I hope to have shown, with the example of wine, that European law, and to some extent also global trends, have been the vector of radical changes in regulation. Administrative action is nowadays made through complex layers of governance, with hybrid modes of governance, and by non-conventional (and only partly public) actors. Where do these developments leave courts? How should courts react to these developments?

Traditionally, judicial accountability has been "upward- and backward-looking: the court looks upward towards the sovereign and backward toward some prior authorization". ${ }^{38}$ What if sovereignty is dispersed amongst many layers of governance and many different actors? What if the authorization is contained in a "norm" which is per se not binding or not even stemming from an "authority"? What is the potential for

\footnotetext{
${ }^{37}$ See e.g. J. Mendes (Ed), EU Executive Discretion and the Limits of the Law (OUP, 2019).

${ }^{38}$ C. Sabel and W. H. Simon, 'Epilogue: Accountability without Sovereignty', in G. de Búrca and J. Scott (Eds.), Law and New Governance in the EU and the US (Hart Publishing, 2006), 398.
} 
courts to act as "catalysts" in such situations? ${ }^{39}$ In other words, how can courts act to enhance and facilitate the realization of the goals and principles that are crucial to the legitimacy of these complex forms of regulation? I would like to make this the main theme of my research agenda. I am lucky enough to have already many colleagues, both in Maastricht and elsewhere, who are as passionate as me to discover more about the scope and application of the principle of effective judicial protection, of shared and transnational administration, of soft law, and of standardization. I hope to be able to contribute to make Maastricht, and the Maastricht Center of European Law, a place where these phenomena keep on being examined and new ideas are generated.

Dear Madam Rector, dear Mr Dean, dear colleagues, dear friends, dear Paul, cara mamma,

I come to point in my inaugural lecture in which I want to thank a number of people who have all, in different ways, contributed to me standing here in front of you today.

First of all, I would like to thank the University Board of Maastricht University and the Faculty Board of the Faculty of Law for having put their trust in me and appointed me for the position which I hold today.

I owe a special word of thank to our Faculty of Law in particular for having made me the scholar I am today. I came to Maastricht as a Master student to attend the Magister Iuris Communis programme, and I have been so lucky to attend courses by Professors such as Jan Smits, Rene de Groot, Aalt-Willem Heringa, Remco van Rhee, Hildegard Schneider, Ellen Vos and many more. They have shown a contagious passion for comparative law, a shared curiosity to search for the common law of Europe and a fearless enthusiasm for turning young students into critical thinkers. I am very proud to say that I am a true Maastricht University product, a place where talent, curiosity and diversity can thrive. I am honoured to be able to continue my work on the shoulders of these giants who have preceded me.

I owe a special debt of gratitude to the Dean of the Law Faculty, Professor Jan Smits, and the head of the Department of Public Law, Professor Gerrit van Maanen, for having shown an immense and continuous trust in me. I promise to do my best to live up to this trust.

A special word of thanks goes to Professor Chris Backes, who has been extremely important for my development as a researcher. Dear Chris, I hope to be able to work further with you for many years to come. Thank you for all what you have taught me, both personally and professionally.

I also want to thank my colleagues at the department of Public Law and at the Maastricht Center of European Law, who contribute to lively discussions on European

\footnotetext{
39 See on this concept, J. Scott and S. Sturm, 'Courts as Catalysts: Re-thinking the Judicial Role in New Governance', 13 Columbia Journal of European Law (2007), 565.
} 
and comparative law. I hope to be able to further work on exciting projects with many of you in the future. A word of gratitude goes also to the speakers of today's congress for agreeing to be there on this special day. Amongst the friends and colleagues who I wish to particularly thank are Natassa Athanasiadou, Sabrina Röttger-Wirtz and Annalisa Volpato, for having helped me with the organization of today's congress, Thu Nguyen, for making my Brussels working days extremely enjoyable and having accompanied me in the preparations of this day, and Catalina Goanta, for always being there to support me.

I also want to thank the many colleagues and friends who have come here to listen to this lecture. Thank you for being with me today, for brightening my life and, of course, for always being ready to drink a glass of wine (or bubbly!) with me.

At this point, I need to thank four great women, who have all, in different ways, contributed to me standing here today in front of all of you. First of all, Professor Rianne Letschert, Rector of Maastricht University, for being a role model for many young academics. Rianne, your passion, heartfelt enthusiasm and vision is a true inspiration. Secondly, Professor Hildegard Schneider, former Dean of the Law Faculty, whose generosity, kindness and passion for research and teaching continues to inspire many amongst us. Thirdly, Professor Ellen Vos, who has accompanied me since my arrival in Maastricht, and have never ceased to believe in me. I am honoured to have your trust and your appreciation, Ellen, and I hope that our friendship will last still for many years to come. Finally, my mother. Cara mamma, grazie per avermi spinto a dare sempre il meglio e grazie per avermi mostrato che ci sono donne che sanno essere, allo stesso tempo, compagne, madri e professioniste. I want to thank my mother because, as Anne-Marie Slaughter put it in her famous article "Why women still cannot have it all", 40 "I owe my own freedoms and opportunities to the pioneering generation of women ahead of me".

Dear Paul, thank you for showing me that, without the shadow of a doubt, French wine is better than Italian one. Only joking, Italian wine is better of course. Cher Paul, despite our irreconcilable enological and gastronomical differences, I still would like to thank you for being, from the beginning, my most enthusiastic supporter. Merci.

The last person I want to thank is my father, who is not here today. I want to thank him for being my role model of honesty, integrity, and passion for work. Those who knew him know for a fact that, if he is watching us from somewhere today, he is getting rather annoyed because he is slowly realizing that he is going to miss a great party.

Dear Madam Rector, dear Mr Dean, dear colleagues, dear friends, dear Paul, cara mamma,

I hold one of the chairs which the Dutch Council for Scientific Research has named after Johanna Westerdijk, the first female professor in the Netherlands. On some

\footnotetext{
40 https://www.theatlantic.com/magazine/archive/2012/07/why-women-still-cant-have-it-all/309020/
} 
aspects, Professor Westerdijk and I differ greatly, because I can take now for granted what she had to fight for: attend the same conference as my male colleagues, have the right to vote or, in fact, be able to have an academic career in the first place. I can only hope to be able to reach her academic achievements. However, one thing we certainly have in common, and here, ladies and gentlemen we come back to where we started: wine. Professor Westerdijk's motto was "Werken en feesten vormt schoone geesten" - working and partying makes happy people. Ladies and gentlemen, the work part is done for the day, it is now time for partying.

Ik heb gezegd. 